\title{
ADORA1 wt Allele
}

National Cancer Institute

\section{Source}

National Cancer Institute. ADORA1 wt Allele. NCI Thesaurus. Code C51396.

Human ADORA1 wild-type allele is located in the vicinity of $1 \mathrm{q} 32.1$ and is approximately $77 \mathrm{~kb}$ in length. This allele, which encodes adenosine A1 receptor protein, plays a role in the regulation of $\mathrm{G}$ protein receptor signal transduction and affects several biological processes. 